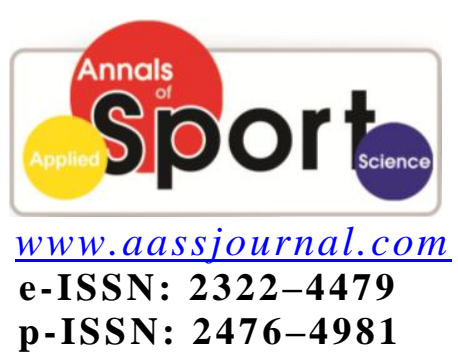

Shoort Connnumication

Received: 01/09/2015

Accepted: 23/12/2015

\title{
A Comparison of Age Average of Iranian Medal Winners in Olympic and Asian Games to their Counterparts from Selected Countries
}

\section{${ }^{1}$ Shiva Jahani Golbar, ${ }^{2}$ Reza Gharakhanlou, ${ }^{3}$ Sara Barmaki, ${ }^{3}$ Ali Khazani", ${ }^{4}$ Mahdi Khorshidi-Hosseini}

1. Department of Physical Education and Sport Science, International Unit of University of Shiraz, Shiraz, Iran.

2. Department of Physical Education and Sports Sciences, Faculty of Humanities, Tarbiat Modares University, Tehran, Iran.

3. Department of Physical Education and Sport Sciences, Faculty of Humanities, Ardabil Branch, Islamic Azad University, Ardabil, Iran.

4. Department of Exercise Physiology, Faculty of Education and Psychology, University of Mohaghegh Ardabili, Ardabil, Iran.

\begin{abstract}
This study attempted to draw a comparison between the age average of Iranian medal winners in Olympic and Asian games and their counterparts from selected countries. The statistical population of the study included Olympic medal winners from the past 100 years and the Iranian who had won medals in 3 rounds of Asian games. The findings indicated that the age average of Iranian medal winners of 3 events (wrestling, weight lifting and taekwondo) at the Olympic games was 24.9 years, while the lowest age average in 3 rounds of Asian games was observed in Boxing (21.8), Karate (23.5), Track and Field (23.5), Fencing (24), Basketball (24), Taekwondo (24.4), Volleyball (24.5), Canoeing (24.6), Judo (24.7), Cycling (24.9) and Soccer (25). The age average of Iranian medal winners showed changes in a reversed U- shape in which the best performance was observed in the 21-28 years age range, while the corresponding age average of Olympic medal winners of the past 100 years in team games was 26-29 years. The age range for speed and strength sports was 22-25 years, while the age range in games requiring not only strength and speed but also high levels of concentration and experience was slightly higher. Professionals, coaches and trainers can utilize the findings of this research to help with scouting, practice planning and development of specialized training protocols for athletes to achieve their set goals.
\end{abstract}

Key Words: Age Average, Iranian, Medal Winners, Olympic Games, Asian Games.

Corresponding Author:

Ali Khazani

E-mail: khazaniali@gmail.com 


\section{INTRODUCTION}

Science development and advancement is a defining characteristic of the era in which we are living. Of the vast number of individuals attempting a variety of sports and games, only a few become champions. Professional sports as a field of physical education have attracted many activists and managers, even from social, cultural and political arenas. Achieving success in international events requires sports trainers and professionals to garner relevant and upto-date information from multiple sources (physiological profile in particular) to help with scouting, nurturing and honing the talents and finally winning continental, world and Olympic medals $(1,2)$.

Studying and recording the age range for championship success in Olympic and continental events is one of the methods for determining one's period of peak performance. Age plays a determinant role in the comprehensive planning of scouting and development of programs for reaching one's performance peak, which in turn is influenced by a number of factors such as sex, environment and characteristics of the target sport. Weight lifting for instance, requires reaching one's peak in strength which occurs in the 20 -30 years age range; while in some athletic disciplines such as shooting, car racing, golf and billiards, the peak period is observed in older ages as speed and strength are overshadowed by experience and practice (1-5).

Generally, athletics are younger in disciplines requiring higher levels of physical activities such as speed and flexibility (for instance in sprint, gymnastics, taekwondo, boxing and karate) (6).

Nybo et al. (2014) investigated the physiological basis of continued world-class performance of a world-class rower who won medals ( 3 gold and 2 bronze) at five consecutive Olympic Games. They reported that until the age of 40 years a steady increase in the oxygen pulse may have compensated for the significant decline in maximal heart frequency. The maintenance of aerobic and anaerobic exercise capacities allowed this Olympic athlete to compete at the highest level for almost two decades (1).

Siegle et al. (1994) analyzed 388 baseball players active in 1965 "to determine the age of peak performance" for skills required to play baseball, to derive age-performance curves for athletic productivity and to assess the magnitude of individual differences among elite and less able players. They examined starting age, exit age and ability relative to career length. They found that the age curve of peak performance rose between ages 19 to 27 and dropped afterwards. This has been associated with the interaction between experience, physiological capacity and motivation levels (3). After examining the profile of Iranian taekwondo contingents at the 2000 Sydney Olympic, Kazemi et al. (2006) reported the ages for male winners and losers to be 24.4 and 25.2 years, respectively. The corresponding ages for female players were 23.1 and 24.9 years, respectively (6) while the age averages of U.S and Czech Republic taekwondo delegates were 25.6 and 18.5 years, respectively. Jafari et al. (2007) reported the corresponding age for Iranian players to be 21 (7). Numerous studies have been carried out regarding the age range of Iranian elite athletes, yet with different accentuation and focus. These studies have reported the age averages for karate, volleyball, table tennis, soccer and wrestling to be $22.25,24.15$, $24.33,24.83$ and 24.4 years, respectively (811).

Although individual and physiologic characteristics of elite athletes active in different athletic disciplines have always been investigated in most researches, age is yet to receive considerable research attention $(4,12)$. Thus, this study attempts to compare age averages of Iranian Olympic and Asian 
games medal winners to champions of various countries from different athletic disciplines to heighten the awareness of athletes, trainers and professionals in this regard and help them in the development of sophisticated and regular plans to facilitate transition from physiological peak to performance peak and demonstrate age as a relative indicator for future planning and prediction.

\section{MATERIALS AND METHODS}

The research design is descriptivecomparative.

Participants. The statistical population comprised 2514 non-Iranian Olympic medal winners from the past 100 years and Iranians who had won medals in 3 rounds of the Asian Olympics (13).

Data Collection. For data collection of Iranian medal winners, we referred to library resources and records of the Iranian National Olympic Academy, Iranian National Olympic Committee (INOC) and relevant Federations. For non-Iranian athletes, data were collected from library resources and authentic, reputable websites (13).

Statistical Analysis. Descriptive statistics methods in form of tables, diagrams and average indicators were employed for data presentation.

\section{RESULTS}

Age averages of Olympic medal winners from across the world. The lowest age averages for men were observed in Asia, America, Africa and Europe, respectively while the lowest age averages for women were in Asia, America, Africa, Oceania and Europe, respectively (Table 1).

The age average of medal winners (both sexes) in Olympic Games in various athletic disciplines. The age averages of medal winners in the Olympic Games during the past 100 years for both men and women were 24.5 and 23 years, respectively. The lowest average for men were observed in table tennis, aquatics, gymnastics, boxing, taekwondo, pentathlon, soccer, judo, kayaking, triathlon, badminton, hockey, wrestling, rowing, weight lifting, track and field, cycling, archery, water polo, baseball, basketball, volleyball, handball, tennis, surfing and horse racing, respectively. For women, the lowest age average was observed in archery, gymnastics, aquatics, wrestling, tennis, taekwondo, table tennis, badminton, volleyball, fencing, judo, swimming, weight lifting, kayaking, track and field, shooting, handball, rowing, soccer, hockey, pentathlon, surfing, basketball, cycling, triathlon and horse racing, respectively (Tables 2 ).

The age average of Iranian medal winners in Olympics and Asian games. The age average of Iranian male medal winners in Asian Games was 24.1, with the lowest average was observed in boxing, karate, track and field, fencing, basketball, weight lifting, wrestling, handball, taekwondo, volleyball, rowing, judo, cycling and soccer while for women, it was observed only in taekwondo (24.7 years). Also, the age average of Iranian male medal winners in the Olympic Games was reported to be 24.9 in wrestling, weight lifting and taekwondo (Tables 1 and 3).

The age average of Iranian medal winners in Olympic and Asian games (Case Studies). The results showed the beginning of peak performance to be in the age range of 20-22 years, winning bronze and silver medals in between and to lesser extent, gold medals. However, the highest levels of success are achieved in 23-26 years age range, followed by a drop in form from age 26 to 28 and as a result, less number of medals are won (Table 4). 
Table 1 . The age average of olympic medal winners across the world.

\begin{tabular}{|c|c|c|c|c|c|c|c|c|c|c|c|}
\hline \multirow[t]{2}{*}{ No } & \multirow{2}{*}{$\begin{array}{l}\text { mainland \& } \\
\text { Country }\end{array}$} & \multicolumn{2}{|c|}{$\begin{array}{c}\text { Age Average } \\
(\mathrm{yr})\end{array}$} & \multirow[t]{2}{*}{ No } & \multirow[t]{2}{*}{ Country } & \multicolumn{2}{|c|}{$\begin{array}{c}\text { Age Average } \\
(\mathrm{yr})\end{array}$} & \multirow[t]{2}{*}{ No } & \multirow{2}{*}{ Country } & \multicolumn{2}{|c|}{$\begin{array}{c}\text { Age Average } \\
(\mathrm{yr})\end{array}$} \\
\hline & & Female & Male & & & Female & Male & & & Female & Male \\
\hline 1 & Asia & 21.9 & 23.4 & 11 & Thailand & 25 & 23.5 & 26 & Russia & 26.2 & 26.3 \\
\hline 2 & Oceania & 24.2 & 24.3 & 12 & Uzbekistan & - & 25.3 & 27 & Turkey & 21 & 25.3 \\
\hline 3 & America & 23.1 & 24.6 & 13 & Azerbaijan & 33 & 25 & 28 & Brazil & 23. & 26 \\
\hline 4 & Africa & 24 & 25.4 & 14 & Belorussia & 28.2 & 22.5 & 30 & Chile & - & 24.5 \\
\hline 5 & Europe & 25.4 & 27 & 15 & Bulgaria & 26.3 & 26 & 31 & Columbia & 35 & - \\
\hline 1 & Iran & - & 24.9 & 16 & Denmark & 26.4 & 27.7 & 32 & Jamaica & 25 & 26.5 \\
\hline 2 & China & 21.8 & 22.3 & 17 & Spain & 27.5 & 25.8 & 33 & The U.S & 22.7 & 24.3 \\
\hline 3 & Hong Kong & 26 & - & 18 & Finland & 26 & 27.1 & 34 & Cameroon & 28 & - \\
\hline 4 & Indonesia & 21 & 25.2 & 19 & France & 25.3 & 28.7 & 35 & Egypt & - & 25 \\
\hline 5 & India & - & 24.5 & 20 & Germany & 24.1 & 26.8 & 36 & Nigeria & 26 & - \\
\hline 6 & Japan & - & 23.6 & 21 & Greece & 26.4 & 24.1 & 37 & R.S.A & - & 23.4 \\
\hline 7 & Kazakhstan & 32 & 24.2 & 22 & Ireland & 26 & 24 & 38 & Ethiopia & 21.3 & 29.5 \\
\hline 8 & S. Korea & 19.4 & 24.6 & 23 & Italy & 28.1 & 25.6 & 39 & Algeria & 24 & 26 \\
\hline 9 & N. Korea & 18 & 24.7 & 24 & Poland & 20.8 & 25.8 & 40 & Australia & 26.3 & 24.2 \\
\hline 10 & Syria & 24 & - & 25 & Romania & 24.2 & 25.2 & - & - & - & - \\
\hline
\end{tabular}

Table 2. The age average of medal winners (both sexes) in Olympic Games in various athletic disciplines.

\begin{tabular}{|c|c|c|c|c|c|c|c|}
\hline \multirow{2}{*}{ No } & \multirow{2}{*}{ Discipline } & \multicolumn{2}{|c|}{ Age Average (yr) } & \multirow[t]{2}{*}{ No } & \multirow{2}{*}{ Discipline } & \multicolumn{2}{|c|}{ Age Average (yr) } \\
\hline & & Female & Male & & & Female & Male \\
\hline 1 & Archery & 19.2 & 26.9 & 20 & Pentathlon & 27 & 23.7 \\
\hline 2 & Track and Field & 25.4 & 25.7 & 21 & Rowing & 26.6 & - \\
\hline 3 & Badminton & 23.5 & 25.4 & 22 & Sail boat & 27.1 & 25.6 \\
\hline 4 & Baseball & - & 27.7 & 23 & Shooting & 26.1 & 31.8 \\
\hline 5 & Basketball & 27.3 & 28 & 24 & Softball & 27.2 & 29.4 \\
\hline 6 & Boxing & & 23.7 & 25 & Aquatics & 20 & 21.6 \\
\hline 7 & Kayaking & 24.8 & 25 & 26 & Table Tennis & 21.6 & 26.4 \\
\hline 8 & Cycling & 29.9 & 26.6 & 27 & Tennis & 21.4 & 23.7 \\
\hline 9 & Horse Racing & 36.8 & 35.7 & 28 & Taekwondo & 20.9 & 29.3 \\
\hline 10 & Fencing & 24.4 & 25.6 & 29 & Triathlon & 34 & 25 \\
\hline 11 & Soccer & 26.8 & 24.1 & 30 & Volleyball & 24 & 28.3 \\
\hline 12 & Gymnastics & 20 & 23.3 & 21 & Weight Lifting & 24.8 & 25.7 \\
\hline 13 & Handball & 4.26 & 28.3 & 22 & Wrestling & 20.3 & 25.6 \\
\hline 14 & Hockey & 26.8 & 25.5 & 23 & Swimming & 24.7 & - \\
\hline 15 & Judo & 24.6 & 24.8 & 24 & Water Polo & 28.6 & 27.5 \\
\hline
\end{tabular}


Table 3. The age average of Iranian medal winners in Asian games.

\begin{tabular}{|c|c|c|c|c|c|c|c|c|c|c|c|}
\hline \multirow{2}{*}{ No } & \multirow{2}{*}{ Dis. } & \multicolumn{2}{|c|}{$\mathrm{N}$ of athletes } & \multicolumn{2}{|c|}{ Age Average (yr) } & \multirow[t]{2}{*}{ No } & \multirow{2}{*}{ Dis. } & \multicolumn{2}{|c|}{$\mathrm{N}$ of athletes } & \multicolumn{2}{|c|}{ Age Average (yr) } \\
\hline & & $\mathrm{F}$ & $\mathrm{M}$ & $\mathrm{F}$ & $\mathrm{M}$ & & & $\mathrm{F}$ & $\mathrm{M}$ & $\mathrm{F}$ & $\mathrm{M}$ \\
\hline 1 & wrestling & - & 25 & 19.2 & 26.9 & 8 & Weight lifting & - & 13 & - & 24 \\
\hline 2 & Soccer & - & 66 & 25.4 & 25.7 & 9 & Boxing & - & 6 & - & 21.8 \\
\hline 3 & Basketball & - & 12 & 23.5 & 25.4 & 10 & Rowing & - & 4 & - & 24.8 \\
\hline 4 & Volleyball & - & 12 & - & 27.7 & 11 & Karate & - & 14 & - & 23.5 \\
\hline 5 & Handball & - & 14 & 27.3 & 28 & 12 & Cycling & - & 12 & - & 24.9 \\
\hline 6 & Judo & - & 12 & & 23.7 & 13 & Fencing & - & 6 & - & 24 \\
\hline 7 & Taekwondo & 3 & 14 & 24.8 & 25 & 14 & Track and Field & - & 5 & - & 23.5 \\
\hline
\end{tabular}

Table 4. Case Studies of Iranian Medal Winners in Olympics and Asian games.

\begin{tabular}{|c|c|c|c|c|c|c|c|c|c|c|c|c|c|}
\hline Dis. & Athlete & Medal & $1^{\text {st }} \mathrm{yr}$ & $2^{\text {nd }} y r$ & $3^{\text {rd }} \mathrm{yr}$ & $4^{\text {th }} \mathrm{yr}$ & Dis & Athlete & Medal & $1^{\text {st }} \mathrm{yr}$ & $2^{\text {nd }} y r$ & $3^{\text {rd }} \mathrm{yr}$ & $4^{\text {th }} \mathrm{yr}$ \\
\hline \multirow{24}{*}{ 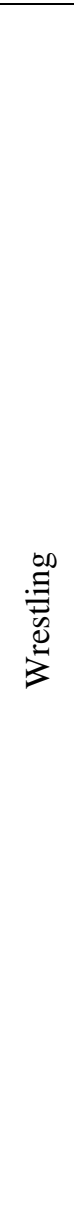 } & & Date & 1952 & 1954 & 1956 & 1960 & \multirow{6}{*}{ 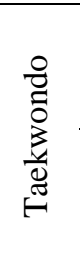 } & \multirow{3}{*}{$\begin{array}{l}I \\
\overline{\tilde{D}} \\
\tilde{\tilde{N}}\end{array}$} & Date & 2000 & 2002 & 2004 & 2008 \\
\hline & 吾 & Medal & $\mathrm{S}$ & $\mathrm{G}$ & $\mathrm{G}$ & $\mathrm{S}$ & & & Medal & B & $\mathrm{G}$ & $\mathrm{G}$ & $\mathrm{G}$ \\
\hline & 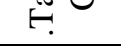 & Age & 22 & 24 & 26 & 30 & & & Age & 24 & 26 & 28 & 32 \\
\hline & \multirow{3}{*}{$\underset{\frac{\mathbb{Z}}{\mathbb{Z}}}{\mathbb{E}} \simeq$} & Date & 1990 & 1992 & 1994 & 1996 & & \multirow{3}{*}{ 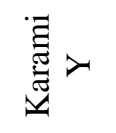 } & Date & 2004 & 2006 & 2008 & 2012 \\
\hline & & Medal & $\mathrm{S}$ & B & $\mathrm{G}$ & $\mathrm{G}$ & & & Medal & S & $\mathrm{G}$ & - & - \\
\hline & & Age & 21 & 23 & 25 & 26 & & & Age & 21 & 23 & 25 & 29 \\
\hline & \multirow{3}{*}{ 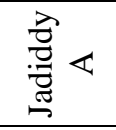 } & Date & 1996 & 1998 & 2002 & - & \multirow{15}{*}{ 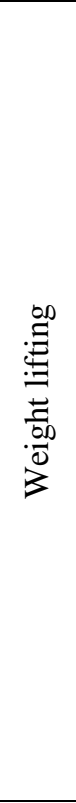 } & \multirow{3}{*}{ 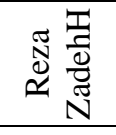 } & Date & 1998 & 2000 & 2002 & 2004 \\
\hline & & Medal & $\mathrm{S}$ & $\mathrm{G}$ & $\mathrm{S}$ & - & & & Medal & B & $\mathrm{G}$ & $\mathrm{G}$ & $\mathrm{G}$ \\
\hline & & Age & 23 & 25 & 27 & - & & & Age & 20 & 22 & 24 & 26 \\
\hline & \multirow{3}{*}{$\begin{array}{l}\varangle \\
:= \\
: \tilde{0}\end{array}$} & Date & 2000 & 2002 & - & - & & $\stackrel{I}{I=}$ & Date & 2000 & 2002 & - & - \\
\hline & & Medal & G & S & - & - & & 竞 & Medal & $\mathrm{G}$ & B & - & - \\
\hline & & Age & 23 & 25 & - & - & & $\stackrel{\pi}{\epsilon}$ & Age & 25 & 27 & - & - \\
\hline & \multirow{3}{*}{ 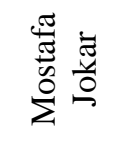 } & Date & 2004 & - & - & - & & \multirow{3}{*}{ 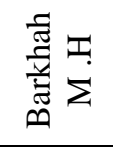 } & Date & 1998 & 2002 & - & - \\
\hline & & Medal & S & - & - & - & & & Medal & S & $S$ & - & - \\
\hline & & Age & 27 & - & - & - & & & Age & 22 & 26 & - & - \\
\hline & \multirow{3}{*}{ 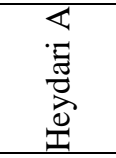 } & Date & 1998 & 2002 & 2004 & 2008 & & \multirow{3}{*}{ 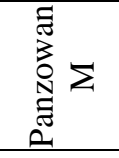 } & Date & 1998 & 2002 & - & - \\
\hline & & Medal & $\mathrm{G}$ & $\mathrm{G}$ & B & $\mathrm{G}$ & & & Medal & B & B & - & - \\
\hline & & Age & 23 & 27 & 29 & 33 & & & Age & 23 & 27 & - & - \\
\hline & \multirow{3}{*}{ 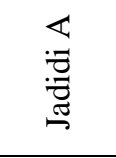 } & Date & 1998 & 2004 & - & - & & \multirow{3}{*}{$\begin{array}{l}\forall \\
\bar{\Xi} \\
\bar{\Xi} \\
\tilde{\Xi} \\
\tilde{D}\end{array}$} & Date & 1998 & 2002 & - & - \\
\hline & & Medal & G & $\mathrm{S}$ & - & - & & & Medal & $\mathrm{S}$ & S & - & - \\
\hline & & Age & 22 & 28 & - & - & & & Age & 23 & 27 & - & - \\
\hline & \multirow{3}{*}{ 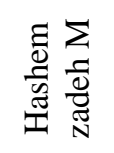 } & Date & 2002 & 2006 & - & - & \multirow{3}{*}{ 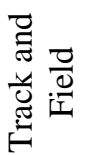 } & \multirow{3}{*}{ 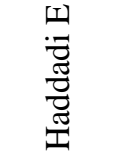 } & Date & 2006 & 2008 & 2012 & - \\
\hline & & Medal & B & $\mathrm{S}$ & - & - & & & Medal & $\mathrm{G}$ & - & $\mathrm{S}$ & - \\
\hline & & Age & 22 & 26 & - & - & & & Age & 22 & 24 & 28 & - \\
\hline
\end{tabular}

\section{DISCUSSION AND CONCLUSION}

The findings indicate that the age averages of Iranian medal winners in individual events and team games in
Olympics and Asian games were 24.9 and 24.1 years, respectively, thus revealing the 22-27 age range as the period of peak performance and winning medals in both 
Olympic and Asian games. The age average of medal winners in the last 100 years in the Olympics turned out to be 24.5 for males and 23 for females, with the variance of ranges based on the nature and characteristics of any given sport.

Players are in the age range of 26-29 in men's team games such as basketball, volleyball and handball where team work rates and experience contribute to success. Lower age averages have been reported for soccer players due to its physical and psychological characteristics. There are even variances in different positions with striking department possessing the lowest average (6, $7)$. The age range is $22-25$ years in individual disciplines such as boxing, wrestling, judo, taekwondo, table tennis and karate in which speed and strength are primary factors.

Where higher levels of concentration and experience are also the case, such as in weight lifting and fencing, the age range goes slightly higher to 24-26 years while the corresponding age range for women is 1 to 2 years lower. Iranian medal winners' age range in team games such as basketball, volleyball and handball is lower compared to the medal winners for the country in the Olympics. The findings highlight the importance of physical and physiological fitness and individual skills performance for inclusion in national levels. However, worldlevel championship success is within reach if team tactics and individual techniques receive equal levels of importance and attention and experience levels are emphasized as well.

Similar results were observed after drawing a comparison between Iranian champions in individual sports such as taekwondo, judo, wrestling and boxing with the country's champions in the Olympics which encourage the employment of talented youths in world and Asian games in these sports. The case studies revealed 20-22 years age range as the period when Iranian athletes' begin to flourish and reach their performance peak which results in winning Asian and/or Olympic silver or bronze medals. Age range 23-26 years is the climax of their performance profile during which most gold and silver medals are won. The dip in form is observed in 26-28 age range which is influenced by a number of physical and physiological characteristics and talent level as well.

There is no saying that a number of external factors such as the general atmosphere of any given sport, facilities and domestic and international rivals in particular, play important roles. A study of age changes over a historical course revealed a reversed U- shape pattern in championship and winning medals, broken down in a 3phase time period from age 21 to 28 years . For instance, the profiles of Iranian highprofile athletes such as Gholam Reza Takhty, Rasool Khadem, Masoud HashemZadeh, Mohammad MostafaJokar and Alireza Dabir in the Olympics and Asian games clearly reflect this pattern. The pattern has also been noticed in some other disciplines such as weight lifting, taekwondo and boxing which Iran have won medals in international games and tournaments. This raises an important question: could the performance profiles of Iranian athletes in a number of disciplines, namely boxing, taekwondo, weight lifting and karate and even track and field be predicted based on the analyses of their age? The examination of the age average of different continents and countries revealed that while Asian countries had the lowest age range, the European countries possesses the highest age range. This is probably due to geographical and environmental differences and employment of different training and scouting programs. For instance China starts its scouting program when children are in their early ages. Chinese athletes deliver the best in 18-24 years age range, while the Europeans reach their peak performance in 
24-28 years. Note that adolescents reach puberty sooner in cold climates than hot climates. Thus we could come to the conclusion that in every society there is a reigning code of behavior and set of beliefs which affects overall planning, expectation and challenges.

\section{CONCLUSION}

Considering the results of the study, it is up to Iranian senior decision- makers in the field to continue with the status quo or take some measures to lower the age average of Iranian candidates competing for a place in the national squads and alter their plans based on the decisions made. However, further research should be conducted in this regards to inform decision making.

\section{APPLICABLE REMARKS}

- The age average of Iranian medal winners showed changes in a reversed U- shape in which the best performance was observed in the 21-28 years age range.

- The age average of Olympic medal winners of the past 100 years in team games was $26-29$ years.

\section{REFFRENCES}

1. Nybo L, Schmidt JF, Fritzdorf S, Nordsborg NB. Physiological characteristics of an aging Olympic athlete. Med Sci Sports Exerc. 2014;46(11):2132-8.

2. Tanaka H, Seals DR. Endurance exercise performance in Masters athletes: age-associated changes and underlying physiological mechanisms. The Journal of physiology. 2008;586(1):55-63.

3. Engebretsen L, Steffen K, Bahr R, Broderick C, Dvorak J, Janarv PM, et al. The International Olympic Committee Consensus statement on age determination in high-level young athletes. British journal of sports medicine. 2010;44(7):476-84.

4. Raschner C, Muller L, Hildebrandt C. The role of a relative age effect in the first winter Youth Olympic Games in 2012. British journal of sports medicine. 2012;46(15):1038-43.

5. Schulz R, Musa D, Staszewski J, Siegler RS. The relationship between age and major league baseball performance: implications for development. Psychology and aging. 1994;9(2):274-86.

6. Kazemi M, Waalen J, Morgan C, White AR. A Profile Of Olympic Taekwondo Competitors. Journal of Sports Science \& Medicine. 2006;5(CSSI):114-21.

7. Jafari A, Agha Alinezhad H, Gharakhanlou R, R. MM. Description And Survey Of Relationship Between Anthropometric And Physiologic Characteristics And Taekwondo Athlete's Success. Olympic. 2007;14(4):7-16 [Article in Farsi].

8. Ghahraman Tabrizi K. A Comparison of Anthropometric, Physiological and Selected Motor Capabilities of Amateur and Elite Volleyball Players. Tehran, Iran: Tarbiat Modares University; 1997.

9. Givechi M. A Comparison of Body Composition, Aerobic Potential, Anaerobic Power and Selected Motor Capabilities of Amateur and Elite Table Tennis Players. Tehran, Iran: Tarbiat Modares University; 1997.

10. Mayeli Kohan M. A Description of Anthropometric features, Physical Fitness and Selected Motor Capabilities of Iranian Elite Soccer Players. Tehran, Iran: Tehran Central Branch, Islamic Azad University; 1997.

11. Mirzaei B, Mansour Sadeghi M. Physical Fitness Profile Of Iranian Senior Free Style Wrestlers Participated In National Training Camp. Olympic. 2007;15(2):81-9 [Article in Farsi].

12. Bernard T, Sultana F, Lepers R, Hausswirth C, Brisswalter J. Age-related decline in olympic triathlon performance: effect of locomotion mode. Experimental aging research. 2010;36(1):64-78.

13. THANH LY G, editor The average age of Olympic champions. 8th International Session for Directors of National Olympic Academies; 2005; Athens, Greece: International Olympic Academy and the International Olympic Committee. 
تازههاى علوم كاربردى ورزش

مقاله كوتاه

دوره سوم، شماره جهارم

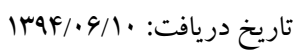

صص 99-V9، زمستان

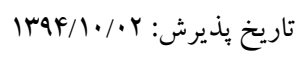

\section{مقابسهى ميانَين سنى قهر مانان و مدالَآوران ايرانى در بازى هاى الميبيك و آسيايح با ساير كثورها}

'شيوا جهانى كَلبر، 'رضا قر اخانلو، 'سارا برمكى، 'على خازنى '، "مهدى خورشيدى حسينى

ا. دانشجوى دكترى فيزيولوزى ورزش، دانشعاه يرديس بين الملل شيراز، شيراز، ايران.

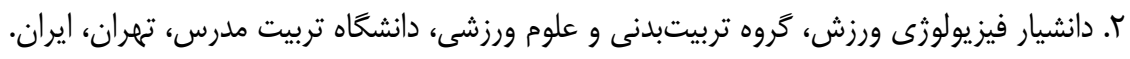

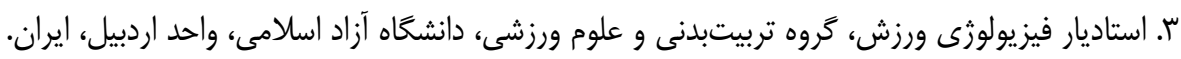

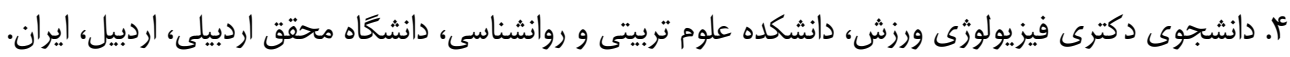

جكيده

هدف از اين تحقيق مقايسه ميانكَين سنى قهرمانان و مدالآور ايرانى با مدالآوران ساير كشورها طى بازىهاى المبيكى و آسيايى بود. جامعه

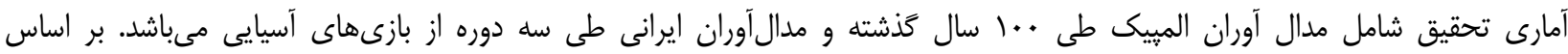

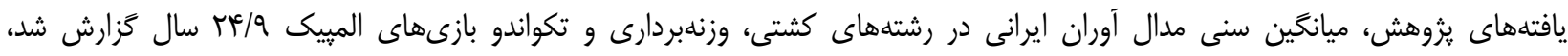

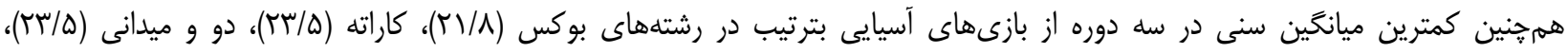

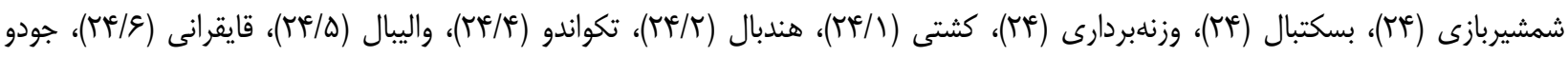

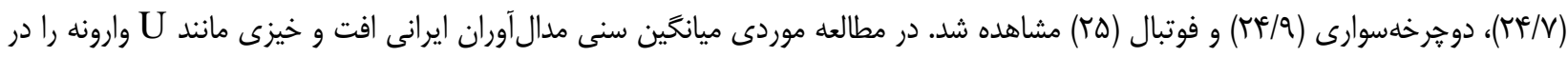

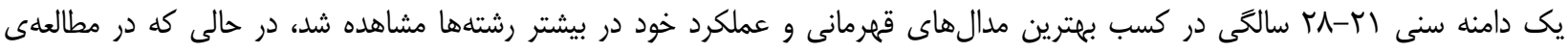

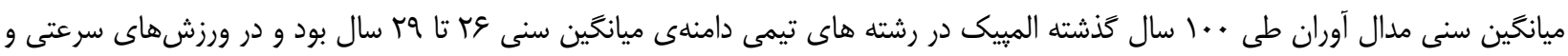

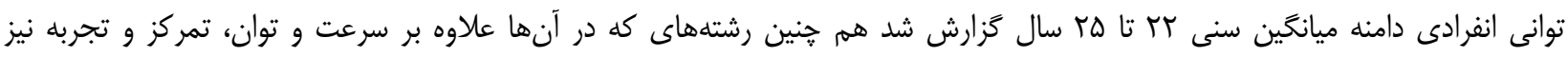

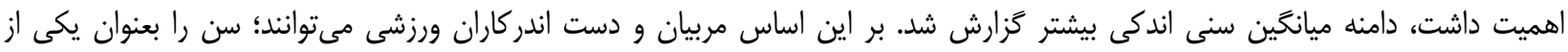

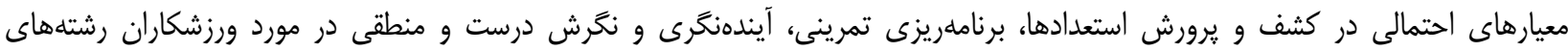

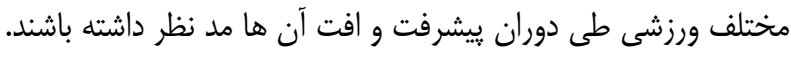
وازَّان كليدى: سن، مدالآوران ايرانى، بازىهاى المبيك، بازىهاى آسيايى.

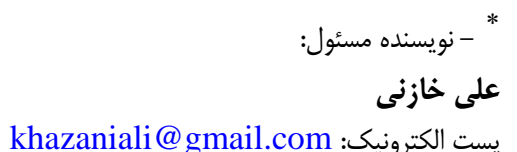

